\title{
Nutritional Composition and Mineral Elements Content Analyses of Lonicera fulvotomentosa Hsu et S. C. Cheng Grown in China
}

Xianghui Jiang ( 381556088@qq.com )

Huaihua University

Longqian Xiao

Huaihua University

\section{Research Article}

Keywords: Karst soil, Pioneer plant, Boron element, Absorption, and transport.

Posted Date: March 15th, 2021

DOI: https://doi.org/10.21203/rs.3.rs-290141/v1

License: (c) (i) This work is licensed under a Creative Commons Attribution 4.0 International License. Read Full License 


\section{Abstract}

Lonicera fulvotomentosa Hsu et S. C. Cheng (L. fulvotomentosa), a vine shrub found in Southwestern China, is used for treating epidemic fever and infectious diseases, such as SARS and Avian Influenza. Here, we investigated the chemical composition and nutritional content of dried flowers of L. fulvotomentosa grown in yellow loam and Karst landform soil in Guizhou, China. The moisture content in all samples varied from 3.25 to $3.63 \%$, lipids from 7.76 to $9.93 \%$, fiber from 6.93 to $7.34 \%$, ashes from 12.32 to $12.76 \%$, crude protein from 7.85 to $8.53 \%$, and carbohydrates from 56.21 to $59.77 \%$. Using inductively coupled plasma-mass spectroscopy (ICP-MS), the predominant mineral elements in the dried flowers were found to be calcium $(297.34-351.26 \mathrm{mg} / \mathrm{kg})$, potassium (132.56-140.37 mg/kg), iron (37.77-41.25 mg/kg), and magnesium (9.47-11.36 mg/kg). Also, HPLC identified flavonoids (kaempferol, rutin, quercetin, luteolin, and apigenin) and phenolic acids (caffeic acid, gallic acid, and chlorogenic acid). Thus, the chemical composition of L. fulvotomentosa was similar to that of Lonicera japonica Thunb. (L. japonica). Thus, it could be used as an alternative to $L$. japonica. Our results showed that the dried flower of $L$. fulvotomentosa had an extremely high content of chlorogenic acids and caffeic acid, which could be developed as a candidate molecule as HIV inhibitors.

\section{Introduction}

For thousands of years, traditional Chinese medicine has been used for treating diseases. L. japonica (add author name) that belongs to Lonicera is an essential medicinal plant widely used in Chinese medicine. The dried flowers of L. japonica are widely used with other traditional Chinese medicines to treat epidemic fever and infectious diseases, such as SARS and Avian Influenza ${ }^{1}$. L. fulvotomentosa is one of the most important variants in the Lonicera family, whose chemical composition and pharmacological effects are similar to $L$. japonica. It is commonly used as a substitute for $L$. japonica ${ }^{2}$. The numerous phytochemicals impart medicinal value to these plants. Previous research indicated that the flower buds of Lonicera species contain various compounds, such as phenolic acids, flavonoids, triterpenoid saponins, and iridoids ${ }^{3}$. Also, trace elements, such as iron (Fe), zinc (Zn), magnesium (Mg), selenium (Se), etc. are also found in plants, which regulate various metabolic processes and oxidative disorders ${ }^{4,5}$. Based on the quantity-activity relationships and the $I_{50}$ values, HAN Jin et al. ${ }^{6}$ illustrate that 3, 5-di0-caffeoylquinic acid (3, 5-diCQA) has a higher affinity for the bacterial cell than 3, 4-di-0-caffeoylquinic acid (3, 4-diCQA) and 4, 5-di-O-caffeoylquinic acid (4, 5-diCQA). Different positions of the caffeoyl ester groups on the cyclohexane ring at C-3, C-4, and C5 result in different anti-bacterial activities for these diCQAs in L. japonica. Caffeoylquinic acid derivatives, as the major active components of the herb, are well-known as potential antioxidants. Furthermore, they have also been reported to possess significant antitumor activity ${ }^{7}$ and potential anti-human immunodeficiency virus (HIV) activity ${ }^{8}$. Thus, the components impart medicinal value to the plants, and thus, scientists are trying to evaluate the nutritional composition of medicinal plants to apply to the field of disease prevention and treatment.

The southwest karst region in China is characterized by fragile ecological environments and strong soil erosion ${ }^{9}$. Features that are exclusive to karst include high concentrations of $\mathrm{Ca}, \mathrm{Mg}$, and $\mathrm{K}$, the lack of surface water, and a very slow rate of soil formation, which pose several challenges for colonizing plants ${ }^{10}$. All these led to the development of a specialized flora with special growth characteristics and nutritional composition. L. fulvotomentosa can grow in karst landform soil and tolerate high calcium, alkaline, and barren soil conditions. It is an important restoration species in the karst landform environment. Wang et al. ${ }^{11}$ determined nine compounds from the acid hydrolysate of the $L$. fulvotomentosa flower buds. These compounds were identified as caffeic acid (CA), ethyl(3ß)-3,23-dihydroxyolean-12-en-28-oate, ethyl caffeate, 5,5-0-dibutoxy-2,2-0-bifuran, $\beta$ sitosterol, nonacosane-10-ol, oleanolic acid, isovanillin, and hederagenin. The inhibitory activity of these compounds against HIV protease was also evaluated, and only ethyl caffeate, CA, and isovanillin exhibited inhibitory effects against human immune deficiency virus (HIV) protease ${ }^{11}$. However, there are no published reports on the detailed composition of the L. fulvotomentosa flowers. Additionally, the nutritional composition and mineral elements contents present in flowers vary depending on the type of soil, the geographical location of the cultivation area, water, and fertilizers. This study aimed to evaluate the nutritional composition and mineral elements contents in L. fulvotomentosa flowers grown in the karst landform environment.

\section{Materials And Methods}




\subsection{Reagents and Standards.}

We obtained HPLC grade methanol $(\mathrm{MeOH})$ and acetonitrile (MeCN) from Thermo Fisher Scientific. Chlorogenic acid (CGA) and gallic acid (GA), quercetin, apigenin, luteolin, rutin, and kaempferol were purchased from Sigma-Aldrich. All other reagents were of analytical grade. The Milli-Q Plus water purification system (Millipore, USA) was used to obtain ultrapure water. The multielement standard mixture solutions contained $\mathrm{Ca}, \mathrm{P}, \mathrm{Fe}, \mathrm{K}, \mathrm{Mn}, \mathrm{Zn}, \mathrm{B}, \mathrm{Mg}, \mathrm{Mo}$, and $\mathrm{Cu}$. Also, $\mathrm{HNO}_{3}(70 \%$ w/v), which was used for digestion and decomposition were purchased from Aladdin Reagent (Shanghai) Co., Ltd.

\subsection{Samples Preparation.}

L. fulvotomentosa flowers which came from Guizhou Congjiang yellow region (located on E $107^{\circ} 20^{\prime} 36^{\prime \prime}$ and N26 $37^{\prime} 24^{\prime \prime}$ ) and Guizhou Xinyi karst soil region (located on E $104^{\circ} 09^{\prime} 26^{\prime \prime}$ and N25 $08^{\prime} 12^{\prime \prime}$ ) respectively. The content of mineral elements in the soil is shown in Table 1. The plants were identified and authenticated by Dr. Xujun Wang, Hunan Academy of Forestry, China. The flowers were cleaned and processed according to the method of Ting et al. (2015) with modifications ${ }^{12}$. We randomly collected six samples from each geographical location. All materials were air-dried, powdered, and kept in the dark in an acclimatization room for further analysis.

Table 1

Mineral element type and content in karst soil and yellow loam

\begin{tabular}{|c|c|c|c|c|c|c|c|c|c|c|c|}
\hline \multirow{2}{*}{$\begin{array}{l}\text { Soil } \\
\text { type }\end{array}$} & \multicolumn{11}{|c|}{ Element and contents } \\
\hline & $\begin{array}{l}N \\
(\mathrm{~g} / \mathrm{kg})\end{array}$ & $\begin{array}{l}P \\
(g / k g)\end{array}$ & $\begin{array}{l}\mathrm{K} \\
(\mathrm{g} / \mathrm{kg})\end{array}$ & $\begin{array}{l}\mathrm{Ca} \\
(\mathrm{g} / \mathrm{kg})\end{array}$ & $\begin{array}{l}M g \\
(g / k g)\end{array}$ & $\begin{array}{l}\mathrm{Fe} \\
(\mathrm{mg} / \mathrm{kg})\end{array}$ & $\begin{array}{l}\mathrm{Mn} \\
(\mathrm{mg} / \mathrm{kg})\end{array}$ & $\begin{array}{l}\mathrm{Zn} \\
(\mathrm{mg} / \mathrm{kg})\end{array}$ & $\begin{array}{l}\text { B } \\
(\mathrm{mg} / \mathrm{kg})\end{array}$ & $\begin{array}{l}\text { Mo } \\
\text { (mg/kg) }\end{array}$ & $\begin{array}{l}\mathrm{Cu} \\
(\mathrm{mg} / \mathrm{kg})\end{array}$ \\
\hline $\begin{array}{l}\text { karst } \\
\text { soil }\end{array}$ & 3.63 & 0.35 & 4.52 & 3.22 & 2.64 & 35.58 & 0.81 & 62.49 & 0.12 & 0.76 & 1.13 \\
\hline $\begin{array}{l}\text { yellow } \\
\text { loam }\end{array}$ & 4.43 & 0.47 & 2. 55 & 2.36 & 1.53 & 62.73 & 0.53 & 75.26 & 0.19 & 0.61 & 0.89 \\
\hline
\end{tabular}

\subsection{Chemical Analysis.}

We dried the samples at $80^{\circ} \mathrm{C}$ in a drought oven till constant weight was obtained for moisture determination. The crude protein/lipid contents were determined based on obtained nitrogen according to the method of AOAC $2000^{13}$. Crude ash content was determined by burning in a muffle furnace at a temperature of $500{ }^{\circ} \mathrm{C}$. The values of crude fiber were determined through the method of Churkova ${ }^{14}$. Total carbohydrates were determined by the phenol sulfuric acid method of Dubois et al. ${ }^{15}$. We determined the energy values ( $\mathrm{kcal} / 100 \mathrm{~g}$ ) by multiplying the values of carbohydrates, lipids, and proteins by factors of 4,9 , and 4 , respectively, and taking the sum expressed in kilocalories ${ }^{16}$.

\subsection{Extraction of Phenolic Compounds.}

We used a dry-ground sample $(30 \mathrm{~g})$ and $80 \% \mathrm{MeOH}(300 \mathrm{~mL})$ to prepare the extract by successive maceration and magnetic stirring for $18 \mathrm{~h}$ at room temperature. Next, the extract was filtered (Whatman No.1), concentrated, frozen for $24 \mathrm{~h}$, and lyophilized. All steps were repeated thrice, and the supernatants were stored at $-40^{\circ} \mathrm{C}$.

\subsection{ICP-MS Analysis.}

We used the MARS-Xpress microwave oven for digestion, followed by elemental analysis via ICP-MS using a XSeries 2 reaction cell (Thermo Scientific). After homogenization, the sample $(0.5 \mathrm{~g})$ was mixed with $\mathrm{HNO}_{3}(65 \% \mathrm{~W} / \mathrm{v} ; 5 \mathrm{~mL})$ and heated in a microwave oven at $50 \%$ power for $10 \mathrm{~min}$ at $150^{\circ} \mathrm{C}$, then at $70 \%$ power for $20 \mathrm{~min}$ at $220^{\circ} \mathrm{C}$, and at $10 \%$ power for $15 \mathrm{~min}$ at $100^{\circ} \mathrm{C}$. We transferred the digested extract into an acid-washed volumetric flask $(50 \mathrm{~mL})$ containing deionized water and stored. Each sample batch had a blank water sample. The modified Kjeldahl procedure was used to determine the total nitrogen content ${ }^{17}$.

\subsection{HPLC-DAD analysis.}


Eight phenolic standards and samples $(25 \mu \mathrm{g} / \mathrm{mL})$ were filtered $(0.45 \mu \mathrm{m})$. We used an Agilent $1200 \mathrm{HPLC}$ system coupled with a diode array detector (DAD) and a C18 RP analytical column $(150 \mathrm{~mm} \times 4.6 \mathrm{~mm}$ and a $3.5 \mu \mathrm{m})$ at $25^{\circ} \mathrm{C}$. We used MeOH and water as the mobile phase with an injection volume of $20 \mu \mathrm{L}$. An aqueous solution of $0.1 \%$ TCA, pH 2.4 , served as the buffer. The sample was eluted at $0.6 \mathrm{~mL} / \mathrm{min}$ via gradient elution: $0-30 \mathrm{~min}: 20$ to $50 \%$ methanol; $30-60 \mathrm{~min}: 50-70 \%$ methanol. The absorbance was recorded at 268 and $354 \mathrm{~nm}$. The data were acquired and analyzed using Agilent 1200 Chemstation software and reported as means \pm standard deviations of three independent analyses.

\subsection{Statistical Analysis.}

We used the Holm-Sidak test and one-way ANOVA to analyze the data that were represented as means \pm SD. A SigmaPlot program v. 11.0 (Windows) was used for analysis. $P<0.05$ indicated statistically significant difference.

\section{Results}

\subsection{Chemical Analysis.}

Table 2 shows the results of nutritional composition analyses of $L$. fulvotomentosa, which plays a crucial role in assessing its medicinal value. We observed an insignificant difference between the composition analyses of the samples that came from karst soil and yellow loam. The result shows that all samples showed variation in moisture content (3.25 to $3.63 \%$ ), lipid content (7.76 to $9.93 \%$ ), fiber (6.93 to $7.34 \%$ ), ashes (12.32 to $12.76 \%$ ), crude protein ( 7.85 to $8.53 \%$ ), and carbohydrates (56.21 to $59.77 \%$ ). The energy values, mainly derived from carbohydrates, varied from 326.21 to $362.57 \mathrm{kcal} / 100 \mathrm{~g}$ according to the method of Mónica et al. ${ }^{16}$.

Table 2

Nutritional composition of dried L. fulvotomentosa

flowers collected from karst soil and yellow loam.

\begin{tabular}{|lll|}
\hline Composition (\%) & karst soil (\%) & yellow loam (\%) \\
\hline Moisture & $3.25 \pm 0.36$ & $3.63 \pm 0.45$ \\
\hline Lipid & $9.93 \pm 1.04$ & $9.76 \pm 0.82$ \\
\hline Fiber & $7.34 \pm 0.66$ & $6.93 \pm 0.57$ \\
\hline Ash & $12.76 \pm 0.84$ & $12.32 \pm 0.45$ \\
\hline Protein & $7.85 \pm 0.93$ & $8.53 \pm 1.12$ \\
\hline Carbohydrates & $59.77 \pm 3.81$ & $56.21 \pm 3.21$ \\
\hline Data represented as mean $\pm S D(n=3)$ \\
\hline
\end{tabular}

\subsection{Elemental Analysis.}

The soil properties (clay, mineralogy, $\mathrm{pH}$ ) are known to be closely related to its mineral composition and the bioavailability of the constituent trace elements. Eleven elements were determined to be present in L. fulvotomentosa collected from karst soil and yellow loam. The concentrations of $\mathrm{N}, \mathrm{P}, \mathrm{K}, \mathrm{Ca}$, and $\mathrm{Mg}$ were determined as $\mathrm{g} / \mathrm{kg}$ for dry flowers, and that of $\mathrm{Mn}, \mathrm{Fe}, \mathrm{Zn}, \mathrm{Cu}, \mathrm{B}$, and Mo, as $\mathrm{mg} / \mathrm{kg}$ (Table 3). The results of the elemental analysis showed significantly higher contents of $\mathrm{Ca}, \mathrm{Mg}$, and Mn in karst soil, while N, P, K, Fe, and Zn were significantly higher in yellow loam. The content differences of Cu, B, and Mo were nonsignificant between yellow loam and karst soil. 
Table 3

Trace element concentration of flowers in L. fulvotomentosa.

\begin{tabular}{|c|c|c|}
\hline Elements (mg/kg) & karst soil & yellow loam \\
\hline Nitrogen $(\mathrm{N})$ & $19842.25 \pm 965.36$ & $27721.63 \pm 1348.45$ *ᄎ \\
\hline Phosphorus (P) & $1487.33 \pm 75.65$ & $2654.43 \pm 135.76^{\star \star}$ \\
\hline Potassium (K) & $8257.34 \pm 231.65$ & $14574.53 \pm 0.57^{\star \star}$ \\
\hline Calcium (Ca) & $20166.26 \pm 564.85^{\star}$ & $17262.92 \pm 465.36$ \\
\hline Magnesium (Mg) & $3827.85 \pm 125.54^{\star *}$ & $3228.53 \pm 178.34$ \\
\hline Manganese (Mn) & $162.19 \pm 3.81^{\star}$ & $116.21 \pm 7.65$ \\
\hline Iron (Fe) & $347.43 \pm 3.81$ & $404.21 \pm 12.48^{*}$ \\
\hline Zinc $(Z n)$ & $74.43 \pm 3.67$ & $115.51 \pm 5.54^{\star}$ \\
\hline Copper (Cu) & $19.64 \pm 1.65$ & $14.26 \pm 1.49$ \\
\hline Boron (B) & $5.08 \pm 0.91$ & $7.25 \pm 1.23$ \\
\hline Molybdenum (Mo) & $0.77 \pm 0.11$ & $1.27 \pm 0.24$ \\
\hline
\end{tabular}

\subsection{Quantification of phenolic acids and flavonoids}

We performed HPLC with DAD detection to identify and quantify the main phenolic acids and flavonoids compounds in the methanolic extracts. We compared the peak areas and retention times among the samples and the standards to quantify the compounds ( $\mu \mathrm{g} / \mathrm{g}$ dry flower), followed by the construction of the calibration curves of the standard compounds.

Figure 1 shows the chromatogram of the standard mixture under optimal conditions, demonstrating efficient purification of the peaks of the phenolic acids and flavonoids standards. The eight compounds were effectively separated within 70 minutes. The eluting peaks were monitored at $268 \mathrm{~nm}$ and $354 \mathrm{~nm}$ between 5 and $65 \mathrm{~min}$. These two wavelengths were used as they covered an extensive range of phenolic compounds: phenolic acids/isoflavonoids at $268 \mathrm{~nm}$ and flavonoids at $354 \mathrm{~nm}$. All phenolic compounds showed a high degree of linearity. We could identify all extracts from the flower of $L$. fulvotomentosa grown in karst soil and yellow loam (Figs. 2-3). The results exhibited a similar pattern of separation with different peak sizes, which indicate the amount/proportion of each compound in the extract. We identified eight phenolic compounds: CGA, quercetin, CA, kaempferol, GA, luteolin, rutin, and apigenin.

For all samples, among phenolic acids, CGA and CA had the highest abundance. Among flavonoids, rutin was the most abundant flavonoid. Table 4 shows the results of the quantitative analysis. The plant cultivated in karst soil contained higher luteolin and kaempferol than those in yellow loam. Besides, the plant cultivated in yellow loam showed larger quantities of rutin and apigenin than in karst soil. The content of CGA and CA are the main indicators to evaluate the quality of honeysuckle; they did not show any significant difference. 
Table 4

The quantitative determination of polyphenolic compounds.

\begin{tabular}{|lll|}
\hline Compound $(\boldsymbol{\mu g} / \mathbf{g})$ & karst soil & yellow loam \\
\hline Gallic acid & $43.54 \pm 3.46$ & $41.87 \pm 3.17$ \\
\hline Chlorogenic acid & $2149.54 \pm 104.35$ & $1938.57 \pm 124.43$ \\
\hline Caffeic acid & $1536.22 \pm 65.43$ & $1418.36 \pm 54.62$ \\
\hline Luteolin & $343.62 \pm 16.26^{*}$ & $283.48 \pm 23.92$ \\
\hline Rutin & $523.35 \pm 21.87$ & $608.38 \pm 31.47^{*}$ \\
\hline Quercetin & $168.49 \pm 6.77$ & $147.63 \pm 5.49$ \\
\hline Kaempferol & $98.36 \pm 4.21^{*}$ & $47.45 \pm 3.66$ \\
\hline Apigenin & $39.25 \pm 3.77$ & $82.15 \pm 2.79 *$ \\
\hline Data are represented as mean $\pm S D(n=3) . * * P<0.001 ; * P<0.05$. \\
\hline
\end{tabular}

\section{Discussion}

The medicinal plants contain various macronutrients, micronutrients, and unique phytochemicals that might be useful for human health. Our results showed that there were no significant changes in the concentrations of ash, moisture, lipid, fiber, protein, and carbohydrates between the two different soils. Additionally, the high ash content $(>12 \%)$ was indicative of flowers being a good source of inorganic minerals. The availability of micronutrients in the soil can strongly affect the production and quality of crops.

Even though essential minerals are generally sufficiently abundant in soils, most of them are in forms that are not easily available to plants. We found that $\mathrm{Ca}, \mathrm{Mg}$, and $\mathrm{Mn}$ were the most abundant mineral elements in the samples from karst soil. In contrast, the Fe and Zn contents were higher in the samples from yellow loam. There is a coordination relationship between the absorption of zinc and iron in plants. The content of $\mathrm{N}, \mathrm{P}$, and $\mathrm{K}$ in samples from karst soil was lower than those from yellow loam. Gawalko et al. (2001) found that soil factors appear to be the major controlling influences on the trace elements ${ }^{18}$. The same cultivar may absorb different amounts of minerals in different soils ${ }^{19}$. Recently, it has been documented in a greenhouse experiment that the $\mathrm{N}$ nutritional status of the plant is a critical tool for agronomic biofortification of wheat with $\mathrm{Zn}$ and $\mathrm{Fe}^{20}$. Soil organic matter exerts a significant and direct effect on the availability of $\mathrm{Zn}$, $\mathrm{Fe}$, and $\mathrm{Mn}$ but has little influence on the availability of soil $\mathrm{Cu}$, so the $\mathrm{Cu}$ content of samples from yellow loam was lower than karst soil. Rice $\mathrm{Zn}$, Fe, and Ca concentrations initially increased and then decreased with a continuous increase in the dose of $\mathrm{N}$. Shortage of fertilizer $\mathrm{K}$ increased plant $\mathrm{Zn}$ and Fe concentrations ${ }^{21}$. The $\mathrm{K}$ content in samples from yellow loam was lower than that from karst soil, which was probably related to the lower content of $\mathrm{Zn}$ and Fe in samples from yellow loam. Increased knowledge of metal homeostasis is an urgent step needed right now to sufficiently understand plant mineral acquisition and storage. This knowledge is expected to efficiently improve crop yield, crop nutritional value, and food safety.

Next, we performed a phytochemical analysis to identify the compounds in the flower extracts. The L. fulvotomentosa samples from karst soil had a higher amount of CGA $(2149.54 \pm 104.35 \mu \mathrm{g} / \mathrm{g})$, luteolin $(343.62 \pm 16.26 \mu \mathrm{g} / \mathrm{g})$, and kaempferol $(98.36 \pm$ $4.21 \mu \mathrm{g} / \mathrm{g})$, whereas samples Came from yellow loam had higher amounts of rutin $(608.38 \pm 31.47 \mu \mathrm{g} / \mathrm{g})$ and apigenin $(82.15 \pm$ $2.79 \mu \mathrm{g} / \mathrm{g})$.

Thus, as previously mentioned, the therapeutic efficacy of $L$. fulvotomentosa could be attributed to the abundance and diversity of flavonoids ${ }^{11}$. Studies have shown the high antioxidant potential of the methanolic extract of the flowers of Lonicera species ${ }^{12}$ could be due to polyphenols and other antioxidants. CGA and its isomers are esters of quinic and CA can inhibit oxidation and 
promote a reduction in obesity, liver lipids, as well as inhibition of acute lung injury ${ }^{22}$. Also, L. fulvotomentosa flowers contain considerable amounts of rutin, which also performs a broad range of physiological activities ${ }^{23}$.

\section{Conclusion}

Thus, we found that $L$. fulvotomentosa was rich in minerals and phenolic components, including natural antioxidants, such as flavonoids and phenolic acids, and thus, might contribute to the therapeutic potential of L. fulvotomentosa. Further clinical and epidemiological studies are required to understand the link between flavonoids and suppression of bacterial growth.

\section{Declarations}

\section{ACKNOWLEDGMENTS}

This study was supported by the Key Project Fund of Hunan Provincial Department of Education (19A390), Foundation of Hunan Double First-rate Discipline Construction Projects of Bioengineering, and the Innovation Platform Project of Education of Hunan Province (16K069).

\section{DATA AVAILABILITY STATEMENT}

The data used to support the findings of this study are available from the corresponding author upon request.

\section{STATEMENT}

We have permission to collect Lonicera fulvotomentosa, this material has been deposited in Specimen Room of Huaihua University, and the deposition number is HHXY2783.

\section{References}

1. Muluye, R. A., Bian, Y. H. \& Alemu, P. N. Anti-inflammatory and Antimicrobial effects of Heat-Clearing Chinese herbs: A Current Review. J. Tradit. Complement. Med. 4, 93-98 (2014).

2. Chun, W., Feng, W. \& Jiang, L.. A comparison of volatile fractions obtained from Lonicera macranthoides via different extraction processes: ultrasound, microwave, Soxhlet extraction, hydrodistillation, and cold maceration. Integr. Med. Res., 4, 171177 (2015).

3. Shang, X., Pan, H. \& Li, M. Lonicera japonica Thunb: Ethnopharmacology, phytochemistry, and pharmacology of an important traditional Chinese medicine. J. Ethnopharmacol, 138, 1-21 (2011).

4. Plus, E., Arnaud, J. \& Ducros, V. Trace element (Cu, Zn, Fe, Mn, Se) intakes of a group of French men using the duplicate diet technique. Int. J. Food Sci. Nutr., 45(1), 63-70 (1994).

5. Shazia, Q., Mohammad, Z. H. \& Rahman, T. Correlation of oxidative stress with serum trace element levels and antioxidant enzyme status in beta-thalassemia major patients: a review of the literature. Anemia, 7, 1-8 (2012).

6. Han, J. LV, Q. Y. \& Jin, S. Y. Comparison of anti-bacterial activity of three types of di-O-caffeoylquinic acids in Lonicera japonica flowers based on microcalorimetry. Chin. J. Nat. Medicines, 12(2), 108-113 (2014).

7. Mishima, S., Inoh, Y. \& Narita, Y. Identification of caffeoylquinic acid derivatives from Brazilian propolis as constituents involved in induction of granulocytic differentiation of HL-60 cells. Bioorg. Med. Chem. Lett., 13 (20): 5814-5818 (2005).

8. Yang, B, Meng, Z. Y. \& Dong, J. X. Metabolic profile of 1,5-dicaffeoylquinic acid in rats, an in vivo, and in vitro study. Drug. Metab. Dispos., 33 (7), 930-936 (2005). 
9. Caili, S., Sixi Z. \& Bin, Z. Effect of Land Use Conversion on Surface Soil Heavy Metal Contamination in a Typical Karst Plateau Lakeshore Wetland of Southwest China. Int. J. Environ. Res. Public Health, 17, 84-89 (2020).

10. Nadia, B., Pablo H. A. D. M. \& Justin, M. A preliminary evaluation of the Karst flora of Brazil Using collections Data. Sci. RepUK., 9, 17037-17049 (2019).

11. Xia W., Ying W. \& Weiyi T. Characterization of Nine Compounds Isolated from the Acid Hydrolysate of Lonicera fulvotomentosa Hsu et S. C. Cheng and Evaluation of Their In Vitro Activity towards HIV Protease. Molecules, 24, 4526-4531 (2019).

12. Ting T., Chang J., \& Hui OuYang. lonic liquid-based ultrasound-assisted extraction and aqueous two-phase system for analysis of caffeoylquinic acids from Flos Lonicerae Japonicae, J. Pharmaceut. Biomed., 12, 134-141 (2016).

13. AOAC. Official Methods of Analysis, 17th ed. (Gaitherbrug, MD, USA, 2000).

14. Churkova, B.G.. Content of Crude Protein, Crude Fiber, and Crude Ash in Dry mass of birdsfoot trefoil varieties and populations. American Journal of Agricultural Science and Technology, 1, 77-83 (2013).

15. Dubois M., Gilles K.A \& Hamilton J.K. Colorimetric Method for Determination of Sugars and Related Substances. Anal. Chem., 28, 350-356 (1956).

16. Mónica, A. Valdez, S. \& Verónica Y. Nutritional Content and Elemental and Phytochemical Analyses of Moringa oleifera Grown in Mexico. J. Chem-NY, 49 (4), 249-256 (2016).

17. Korn, Md., Dos Santos, W. P. \& Korn M. Optimization of focused-microwave assisted digestion procedure for Kjeldahl nitrogen determination in bean samples by factorial design and Doehlert design. Talanta, 65 (3):701-715 (2005).

18. Gawalko E.J., Garret R.G. \& Nowicki T.W. Trace elements in western Canadian hard red spring wheat (Triticum aestivum L.): Levels and quality assurance. The Journal of Aoac International, 84, 1953-1963 (2001).

19. Zlatko, S., Marina, J. \& Marija, B. Trace element concentrations in the grain of wheat cultivars as affected by nitrogen fertilization. Agr. Food Sci., 22(4), 445-451 (2013).

20. Kutman U. B., Yildiz B. \& Cakmak I. Improved nitrogen status enhance zinc and iron concentrations both in the whole grain and the endosperm fraction of wheat. J. Cereal. Sci., 53, 118-125 (2011).

21. Li B. Y., Zhou D. M. \& Cang L. Soil micronutrient availability to crops as affected by long-term inorganic and organic fertilizer applications. Soil Till. Res., 96, 166-173 (2007).

22. Zhang X., Huang H. \& Yang T. Chlorogenic acid protects mice against lipopolysaccharide-induced acute lung injury. Injury, 41(7):746-752 (2010).

23. Suzuki T., Honda Y. \& Mukasa Y.. Effects of UV-B radiation cold and desiccation stress on rutin concentration and rutin glucosidase activity in Tartary buckwheat (Fagopyrum tataricum) leaves. Plant Sci., 168(5), 1303-1307 (2005).

\section{Figures}




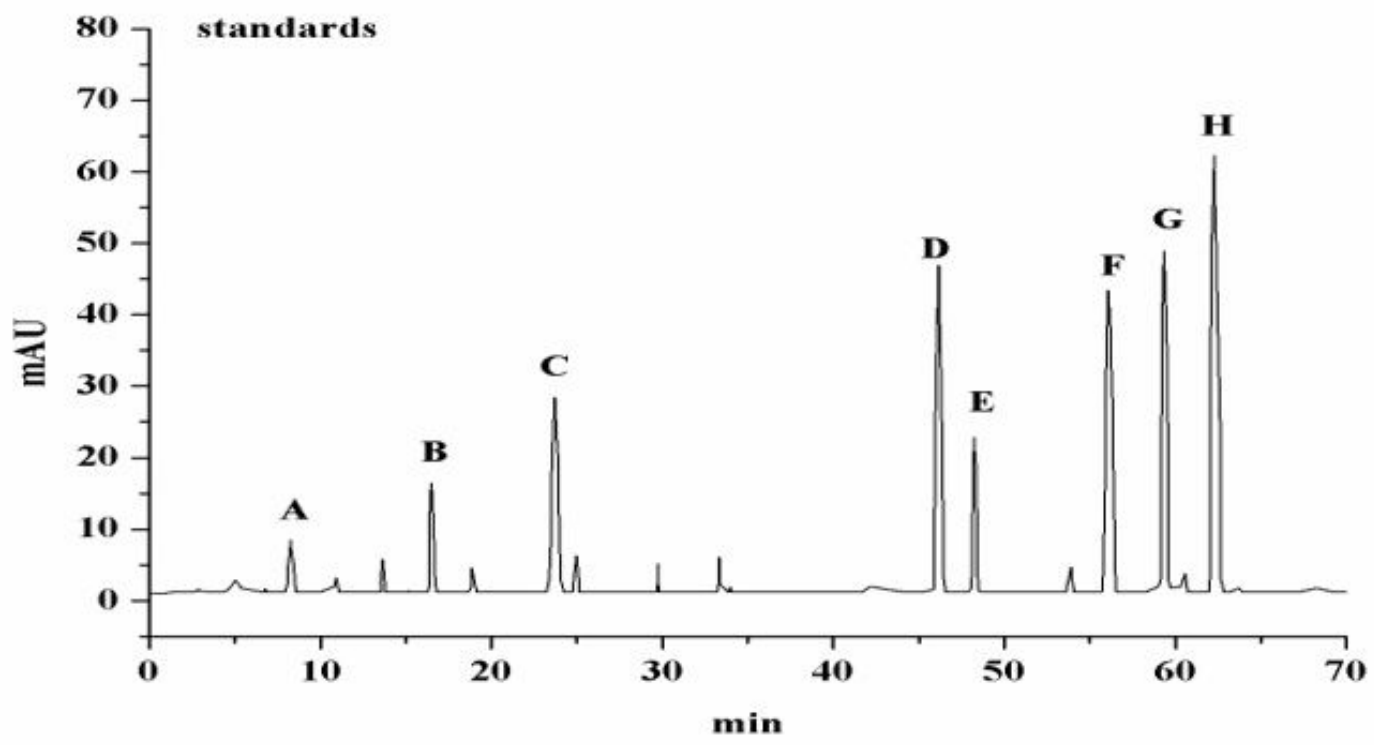

Figure 1

Chromatogram of the reference substances of phenolic acids and flavonoids. Note: A: Gallic acid; B: Chlorogenic acid; C: Caffeic acid; D: luteolin; E: rutin; F: quercetin; G: kaempferol; H: apigenin.

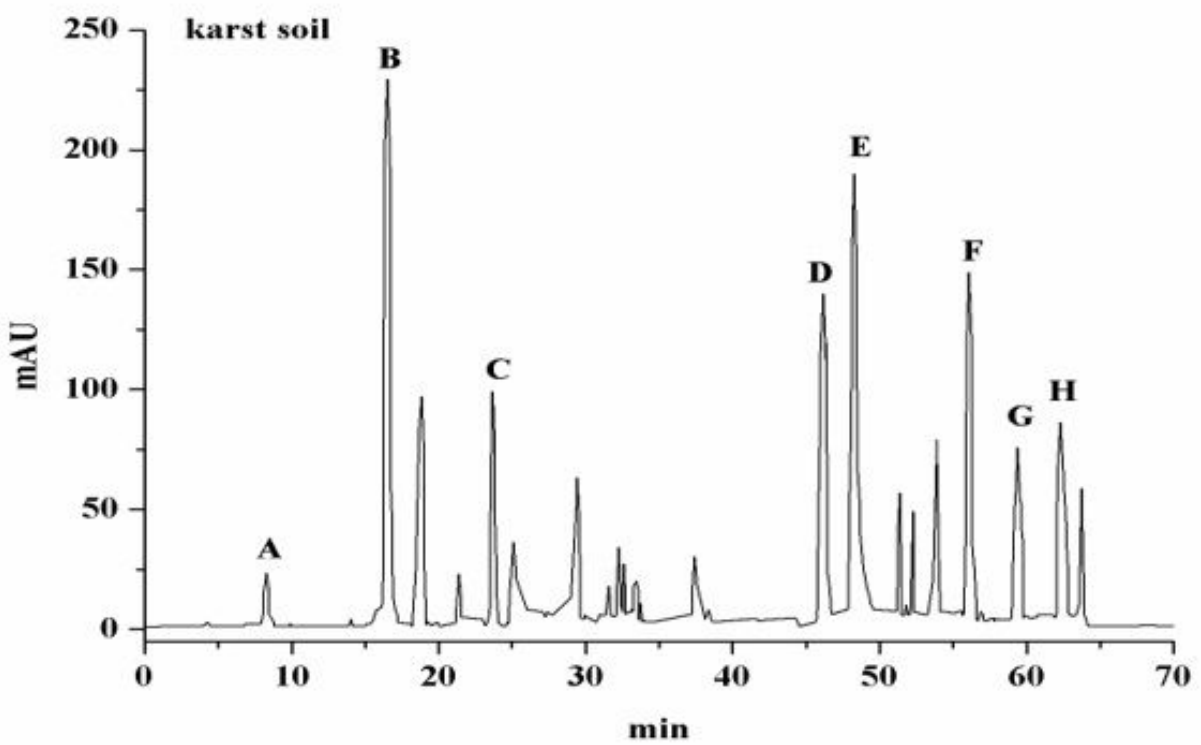

Figure 2

HPLC analyses of L. fulvotomentosa sample from karst soil. 


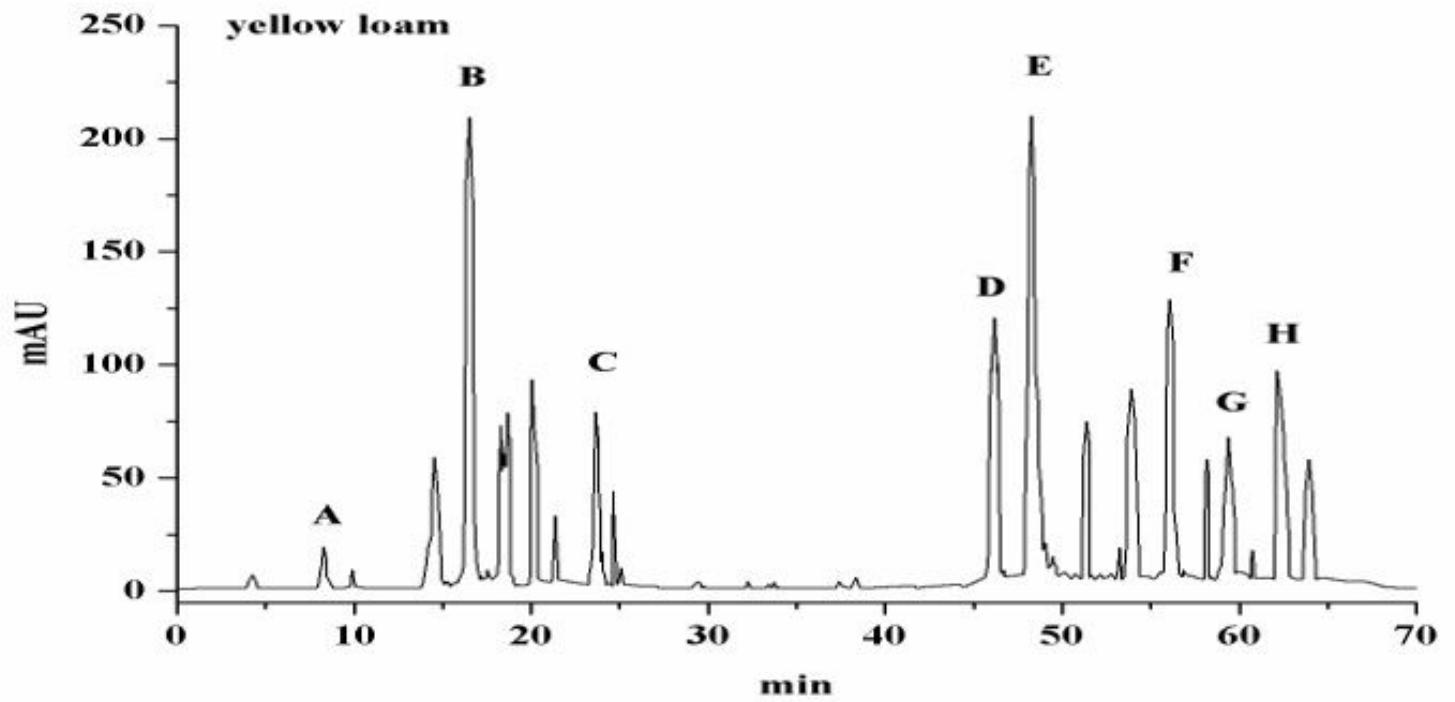

Figure 3

HPLC analyses of L. fulvotomentosa sample from yellow loam. 